\title{
PENGARUH KEPERCAYAAN SISWA PADA MATEMATIKATERHADAP KEMAMPUAN PEMECAHAN MASALAH MATEMATIS SISWA
}

\author{
AMINULLAH \\ Fakultas Teknik UNMAS Denpasar PSDKU Mataram \\ e-mail :aminullahmtk@gmail.com
}

\begin{abstract}
ABSTRAK
Penelitian ini bertujuan untuk mendeskripsikan pengaruh kepercayaan siswa pada matematika terhadap kemampuan pemecahan masalah matematis siswa. Jenis penelitian ini merupakan penelitian eksperimen semu dan sampel dalam penelitian ini yaitu siswa kelas XI jurusan akomodasi perhotelan sejumlah 31 siswa. Pengambilan data menggunakan instrumen angket dan tes. Hasil penelitian ini diperolehrata-rata kepercayaan siswa pada matematika sebesar 60,23 dengan standar deviasi sebesar 3,66. Sedangkan kemampuan pemecahan masalah matematis siswa diperoleh rata-rata 66,94 dengan standar deviasi 9,63. Kepercayaan siswa pada matematika dan kemampuan pemecahan masalah matematis siswa tergolong cukup. Ada pengaruh kepercayaan siswa pada matematika terhadap kemampuan pemecahan masalah matematis siswa ditunjukkan dengan $\mathrm{F}$ hitung $(4,746) \geq \mathrm{F}$ tabel $(4,18)$ atau angka signifikansi pada ANOVA0,038 $\leq 0.05$. Besarnya pengaruh kepercayaan siswa pada matematika terhadap kemampuan pemecahan masalah matematis siswa sebesar $14,1 \%$. Persamaan regresi yang diperoleh $\widehat{\boldsymbol{Y}}=7,455+0,988 \boldsymbol{X}$ $+\epsilon$. Artinya jika nilai kepercayaan siswa pada matematika sebesar 1 satuan, maka nilai variabel prediksi akan bertambah sebesar 0,988. Semakin tinggi kepercayaan siswa pada matematika, maka kemampuan pemecahan masalah matematis siswa juga akan semakin meningkat.
\end{abstract}

Kata Kunci: kepercayaan pada matematika, kemampuan pemecahan masalah matematis.

\section{ABSTRACT}

This study aims to describe the effect of student confidence in mathematics on students' mathematical problem solving abilities. This type of research is a quasiexperimental study and the sample in this study is a class XI student majoring in hotel accommodation with 31 students. Retrieval of data using questionnaire and test instruments. The results of this study obtained the average student confidence in mathematics at 60.23 with a standard deviation of 3.66. While the mathematical problem solving abilities of students obtained an average of 66.94 with a standard deviation of 9.63. Students 'trust in mathematics and students' mathematical problem solving abilities are quite sufficient. There is an influence of students 'trust in mathematics on students' mathematical problem solving abilities indicated by $F$ count $(4,746) \geq F$ table $(4,18)$ or significance number at 0,038 $\leq 0.05$ ANOVA. The magnitude of the influence of student confidence in mathematics on students' mathematical problem solving abilities is $14.1 \%$. The regression equation obtained by $Y^{\wedge}=7.455+0.988 X+\epsilon$. This means that if the value of student confidence in mathematics is 1 unit, then the value of the predictive variable will increase by 0.988. The higher the confidence of students in mathematics, the mathematical problem solving abilities of students will also increase

Keywords: trust in mathematics, mathematical problem solving abilities 


\section{PENDAHULUAN}

\section{Latar Belakang}

Matematika merupakan salah satu pelajaran yang masih ditakuti oleh sebagian siswa karena identic dengan rumus-rumus dan menghitung. Rasa takut terhadap matematika mengakibatkan kemalasan dalam belajar khususnya bagi siswa di Sekolah kejuruan yang mengambil jurusan yang tidak berhububgan langsung dengan matematika misalnya tata busana, boga, perhotelan dan jurusan lain yang sejenis, berbeda dengan siswa SMA terutama yang jurusan IPA yang melihat matematika seperti mata pelajaran lain pada umumnya. Rasa takut yang akhirnya sulit memahami matematika dapat dikatakan karena ketidak percayaan terhadap matematika itu sendiri.Kepercayan siswa pada matematika adalah persepsi pribadi yang dimiliki oleh siswa baik secara implisit maupun eksplisit.Persepsi tersebut tentang pendidikan matematika, tentang dirinya sendiri sebagai matematikawan, dan tentang konteks matematika dalamkelas (Eynde, De Corte, dan Verchaffel, 2002).Jadi kepercayaan terhadap matematika dapat dikatakan bahwa persepsi pribadi mengenai kebermanfaatan matematika di masa depan, baik hubungannya dengan mata pelajaran lain ataupun penggunaannya di masa yang akan datang setelah meninggalkan bangkau sekolah.

Kepercayaan terhadap matematika itu penting supaya menumbuhkan minat untuk memepelajarinya dan termotivasi untuk belajar sehingga mampu memecahkan permasalahan matematika.Eynde, De Corte, dan Verchaffel (2002) mengemukakan bahwa secara umum para peneliti melihat adanya hubungan yang signifikan antara kepercayaan siswa dengan pengaruhnya kepada pembelajaran matematika dan penyelesaian masalah.Menurut Pehkonen dan Pietila (2003) kepercayaan pada matematika adalah pengetahuan subjektif yang dimiliki seseorang, dan mungkin saja benar maupun salah.Jika kepercayaan terhadap matematika itu rendah atau kepercayaan yang negatif, maka dapat menjadi penghalang untuk dapat memahami matematika itu sendiri, seperti yang dikatakan oleh Pehkonon (2001) bahwa kepercayaan memiliki pengaruh yang besar bagaimana seseorang belajar dan menggunakan matematika, oleh karena itu bisa juga menjadi penghalang dari pembelajaran matematika yang efektif. Sejalan dengan pendapat Kloosterman (2002) yang menyatakan bahwa kepercayaan siswa pada matematika adalah apa yang diketahui dan dirasakan siswa pada matematika dan akan mempengaruhi usaha yang dilakukannya tentang matematika.Mitos dan kepercayaan tentang matematika siswa sangat berpengaruh pada kesukaan atau ketidaksukaan siswa terhadap matematika (Mutodi dan Ngirande, 2014).

Ketika suka terhadap matematika maka akan menimbulkan rasa ingin tahu tentang matematika itu sendiri, sehingga belajar matematika akan menyenangkan. Rasa suka atau persepsi tersebut dapat timbul karena percaya terhadap matematika bisa bermanfaat di masa depan. Pemikiran tentang kebermanfaatan matematika di masa depan pasti sudah terpikirkan oleh siswa tingkat SMA. Artinya bahwa siswa SMA sudah mampu memilih mata pelajaran yang ditekuni berdasarkan pertimbangan logika, bukan hanya lagi karena rasa suka atau menyenangkan untuk dipelajari.Menurut Goldin, Rosken dan Torner (2009) bahwa bahwa belief matter, kepercayaan memberikan perbedaan pengaruh pada setiap orang yang terlibat dalam matematika. Kepercayaan atau persepsi siswa terhadap matematika dapat terbentuk karena pengalaman siswa di masa lampau dan juga dapat terbentuk dari lingkungan belajar, baik dari teman sejawat, guru atau media belajar lainnya. Jika kepercayaan siswa terhadap matematika itu salah maka belajar matematika tidak akan menyenangkan, sehingga akan kesulitan dalam memecahkan masalah matematika dan berujung pada hasil belajar yang kurang. Sesuai menurut Chacon, Madruga, Rodríguez,dkk (2011) yang menyatakan bahwa nilai dari tes kognitif,kepercayaan pada matematika, dan kepercayaan pada kompetensi sendiri dapatmenjadi prediksi dari kinerja matematika.Siswa pada dasarnya diharapkan memiliki kepercayaan terhadap matematika supaya mampu meningkatkan motivasi belajar sehingga mampu memecahkan masalah matematika untuk memperoleh hasil belajar yang memuaskan.

Kemampuan pemecahan masalah adalah kemampuan untuk berpikir tingkattinggi untuk menemukan berbagai macam cara penyelesaian masalah pada suatupersoalan dan menemukan satu yang sesuai sehingga dapat mencapai tujuan yangdiinginkan (Nitko dan Brookhart, 2011). Belajar matematika identic dengan pemecahan masalah dalam menjawab soal-soal atau permasalahan matematika.Sehingga siswa diharapkan memiliki kemampuan pemecahan masalah khususnya dalam matematika.Menurut.Adams dan Hamm(2010) bahwa kemampuan pemecahan masalah sebagai aplikasimatematika, yaitu menghitung, mendefinisikan, mengimplementasi, danmemperhatikan daerah solusi.Sependapat dengan Bruning, Schraw, dan Norby (2011) yang mengemukakan bahwa siswa yang memiliki kemampuan pemecahan masalah akan mampu untukmemahami masalah, merepresentasikan masalah, memilih strategi yang sesuaiuntuk penyelesaian masalah, mengimplementasikan strategi, dan mengevaluasisolusi. Kemampuan pemecahan masalah akan menjadikan siswa percaya diri ketika diberikan masalah-masalah untuk menguji tingkat kemampuan siswa atau hasil belajar siswa. kemampuan pemecahan masalah matematika tidak dapat diperoleh kecuali dengan 
belajar dan latihan-latihan pemecahan masalah, latihan yang kontinyu akan dapat dilakukan jika siswa merasa suka atau memiliki kepercayaan terhadap matematika. Seorang yang memiliki kemampuan pemecahan masalahmaka akan mampu mengidentifikasi permasalahan, apa kesulitan dalammenyelesaikan permasalahan, dan apa yang kemungkinan menjadi solusinya(Brookhart, 2010). Menurut Hudoyo (1979) bahwa pemecahan masalahmerupakan suatu hal yang esensial dalam pembelajaran matematika, sebab:a. Siswa menjadi terampil menyeleksi informasi yang relevan, kemudianmenganalisanya dan akhirnya meneliti hasilnya;b. Kepuasan intelektual akan timbul dari dalam, merupakan masalah intrinsic bagi siswa;c. Potensial intelektual siswa meningkat;d. Siswa belajar bagaimana melakukan penemuan dengan melalui prosesmelakukan penemuan.

De Bono (Bruning, Schraw, dan Norby, 2011) mengemukakan terdapat5 kemampuan yang menjadi aspek dari kemampuan pemecahan masalah, yaitumerencanakan, memunculkan alternatif, menganalisis, membandingkan, memilih,dan mengevaluasi.Sedangkan Bransford dan Stein (Nitko dan Brookhart, 2011) membedakan kemampuanpemecahan masalah dalam lima tahapan, yaitu I (identifikasi masalah), D (define/mendefinisikan masalah), E (explore/mencari berbagaistrategi yang mungkin), A(act/melakukanstrategi), L(look back/melihat kembalidan mengevaluasiaktifitas).Jadi kemampuan pemecahan masalah matematika merupakan kemampuan untuk memahami masalah, merencanakan strategi penyelesaian masalah, memilih strategi yang tepat untuk menyelesaikan masalah, melaksanakan strategi penyelesaian masalah dan mengevaluasi setiap tahapan penyelesaian maslah matematika.

\section{Rumusan Masalah}

Berdasarkan latar belakang, maka rumusan masalah dalam penelitian ini yaitu“apakah ada pengaruh kepercayaan siswa pada matematika terhadap kemampuan pemecahan masalah matematissiswa ?".

\section{Tujuan Penelitian}

Tujuan penelitian ini adalah untuk mendeskripsikan pengaruh kepercayaan siswa pada matematika terhadap kemampuan pemecahan masalah matematis siswa.

\section{METODE PENELITIAN}

Jenis penelitian yang digunakan dalam penelitian ini merupakan penelitian eksperimen semu dan sampel dalam penelitian ini yaitu siswa kelas XI jurusan akomodasi perhotelan (AP 2) SMKN 4 Mataram sejumlah 31 siswa.Penelitian ini dilaksankan bulan April 2019 dengan pengambilan data menggunakan instrumen angket dan tes. Tes digunakan untuk memperoleh data mengenai kemampuan pemecahan masalah matematika siswa dan angket digunakan untuk mendapatkan data mengenai kepercayaan siswa terhadap matematika.Analisis data menggunakan analisis regresi linear sederhana dengan persamaan $\widehat{Y}=a+b X+$ $\epsilon$.Namun sebelum dilakukan ujni regresi, terlebih dahulu data harus memenuhi uji asumsi klasik meliputi normalitas, linearitas dan heteroskedastisitas.Adapun hipotesis yang diuji dalam menentukan pengaruh kepercayaan siswa pada matematika terhadap kemampuan pemecahan masalah matematis siswa sebagai berikut :

Ho : Tidak ada pengaruh kepercayaan siswa pada matematika $(X)$ terhadap kemampuan pemecahan masalah matematis siswa $(Y)$.

Ha: Ada pengaruh kepercayaan siswa pada matematika $(X)$ terhadap kemampuan pemecahan masalah matematis siswa $(Y)$.

Pengujian untuk menunjukkan kebenaran hipotesis diatas dibuktikan dari pengaruh variabel $\mathrm{X}$ pada variabel $\mathrm{Y}$ dalam analisis regresi, dengan ketentuan sebagai berikut:

Ho ditolak/ Ha diterima : Jika F hitung $\geq \mathrm{F}$ tabel atau angka signifikansi pada ANOVA sebesar $\leq 0.05$

Ho diterima/ Ha ditolak : Jika F hitung < Ftabel atau angka signifikansi pada ANOVA sebesar > 0.05 16.0 .

Pengolahan, analisis serta pengujian data dalam penelitian ini menggunakan bantuan software SPSS

\section{HASIL DAN PEMBAHASAN}

Hasil dari penelitian ini mendeskripsikan tentang pengaruh kepercayaan siswa pada matematika terhadap kemampuan pemecahan masalah matematis siswa.Kepercayaan siswa pada matematika yang diukur menggunakan angket diperoleh rata-rata dari 31 siswa sebesar 60,23 dengan standar deviasi sebesar 3,66. 
Sedangkan kemampuan pemecahan masalah matematis siswa diperoleh rata-rata siswa sebesar 66,94 dengan standar deviasi sebesar 9,63. Artinya bahwa kepercayaan siswa pada matematika dan kemampuan pemecahan masalah matematis siswa tergolong cukup.

Data yang sudah diperoleh mengenai kepercayaan siswa pada matematika dan kemampuan pemecahan masalah matematis siswa terlebih dahulu dilakukan uji prasayarat atau uji asumsi klasik sebelum melanjutkan ke uji regresi sederhana.Uji asumsi meliputi normalitas, linieritas dan heteroskedastisitas.Uji normalitas dalam penelitian ini menggunakan uji statistic non-parametric Kolmogrov-Smirnov (KS).Menurut Ghozali (2011), data dikatakan memiliki residual terdistribusi normal jika nilai KolmogrovSmirnovlebih besar dari nilaiAsymp sig.Berdasarkan analisis diperoleh hasil nilai Kolmogrov-Smirnov sebesar 1,083 sedangkan nilai Asymp sig sebesar 0,191. Menunjukkan bahwaKolmogrov-Smirnov>Asymp sig, sehingga dapat dikatakan bahwa data residual terdistribusi normal.Adapun tabel hasil analisis normalitas dapat dilihat pada tabel 1 di bawah.

Tabel 1. One-Sample Kolmogorov-Smirnov Test

\begin{tabular}{|ll|r|r|}
\hline & & Kepercayaan (X) & PemecahanMasalah (Y) \\
\hline $\mathrm{N}$ & & 31 & 31 \\
Normal Parameters $^{\mathrm{a}}$ & Mean & 60.2258 & 66.9355 \\
& Std. Deviation & 3.65796 & 9.63305 \\
Most Extreme Differences & Absolute & .164 & .195 \\
& Positive & .102 & .117 \\
& Negative & -.164 & -.195 \\
Kolmogorov-Smirnov Z & & .916 & 1.083 \\
Asymp. Sig. (2-tailed) & .372 & .191 \\
\hline a. Test distribution is Normal. & & \\
\hline
\end{tabular}

Uji asumsi atau uji prasyarat lainnjya yaitu uji liniearitas.Adapun hasil uji linearitas dapat dilihat pada tabel 2 berikut.

Tabel 2. ANOVA Table

\begin{tabular}{|lll|r|r|r|r|r|}
\hline & & Sum of Squares & df & Mean Square & \multicolumn{1}{c|}{ F } & Sig. \\
\hline Pemecahan.Masalah Between & (Combined) & 1233.871 & 13 & 94.913 & 1.041 & .460 \\
* Kepercayaan & Groups & Linearity & 391.545 & 1 & 391.545 & 4.294 & .054 \\
& Deviation from & 842.326 & 12 & 70.194 & .770 & .673 \\
& Linearity & 1550.000 & 17 & 91.176 & & \\
& & 2783.871 & 30 & & & \\
\hline
\end{tabular}

Jika Deviation from linearity sig. pada ANOVA $\geq 0,05$ maka terdapat hubungan yang liniear antara variable $X$ dan variable $Y$. berdasarkan tabel 2 di atas dapat dilihat bahwa nilai Deviation from linearity sig. pada ANOVA sebesar 0,673 yang menunjukkan lebih besar dari $0,05(0,673 \geq 0,05)$, artinya bahwa terdapat hubungan yang liniear antara variable $X$ dan variable $Y$.Sedangkan untuk hasil uji heteroskedastisitas dapat dilihat pada gambar 1 berikut.

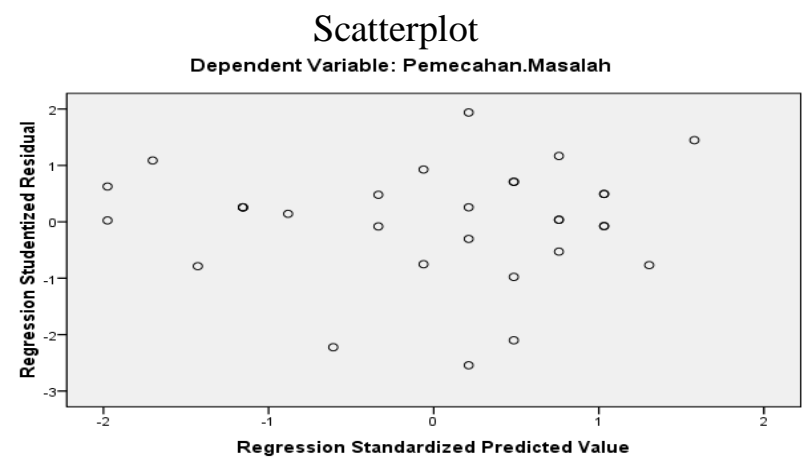

Gambar. Grafik Plot 
Menurut Ghozali (2011), model regresi yang baik adalah yang homoskedastisitas atau tidak terjadi heteroskedastisitas. Jika tidak ada pola yang jelas, serta titik-titik menyebar di atas dan dibawah angka 0 pada sumbu Y, maka tidak terjadi heteroskedastisitas. Dapat dilihat pada gambar 1 bahwa titik-titik menyebar secara acak serta tersebar di atas maupun di bawah angka 0 pada sum bu $\mathrm{Y}$, artinya tidak terjadi heteroskedastisitas pada model regresi dan layak dipakai.

Hasil penelitian yang sudah memnuhi uji asumsi prasyarat, maka di lanjutkan dengan analisis regresi dengan hasil dapat dilihat pada Tabel 3 berikut.

\begin{tabular}{l} 
Tabel 3. ANOVA \\
\begin{tabular}{|ll|r|r|r|r|c|}
\hline Model & & Sum of Squares & df & Mean Square & F & Sig. \\
\hline 1 & Regression & 391.545 & 1 & 391.545 & 4.746 & $.038^{\mathrm{a}}$ \\
& Residual & 2392.326 & 29 & 82.494 & & \\
& Total & 2783.871 & 30 & & & \\
\hline
\end{tabular} \\
a. Predictors: (Constant), Kepercayaan \\
b. Dependent Variable: PemecahanMasalah \\
\hline
\end{tabular}

Berdasarkan hipotesis yang sudah diajukan sebelumnya, bahwa jika $\mathrm{F}$ hitung $\geq \mathrm{F}$ tabel atau angka signifikansi pada ANOVA sebesar $\leq 0.05$ maka Ho ditolak/ Ha diterima. Sedangkan jika F hitung < Ftabel atau angka signifikansi pada ANOVA sebesar $>0.05$ maka Ho diterima/ Ha ditolak. Sesuai dengan yang di tunjukkan pada tabel 3 di atas, terlihat jelas bahwa Fhitung $(4,746) \geq \mathrm{F}$ tabel $(4,18)$ atau angka signifikansi pada ANOVA0,038 $\leq 0.05$, sehingga Ha diterima/ Ho ditolak. Hal ini berarti bahwa Ada pengaruh kepercayaan siswa pada matematika $(X)$ terhadap kemampuan pemecahan masalah matematis siswa (Y).Sedangkan untuk mengetahui besarnya pengaruh kepercayaan pada matematika terhadap kemampuan pemecahan masalah matematis siswa dapat dilihat dari tabel berikur.

Tabel 4. Model Summary

\begin{tabular}{|l|c|r|r|c|}
\hline Model & $\mathrm{R}$ & $\mathrm{R}$ Square & $\begin{array}{c}\text { Adjusted R } \\
\text { Square }\end{array}$ & $\begin{array}{c}\text { Std. Error of the } \\
\text { Estimate }\end{array}$ \\
\hline 1 & $.375^{\mathrm{a}}$ & .141 & .111 & 9.08262 \\
\hline
\end{tabular}

$R$ Square pada tabel 4 sebesar 0,141 yang menunjukkan besarnya pengaruh $X$ terhadap $Y$. Artinya pengaruh kepercayaan siswa pada matematika terhadap kemampuan pemecahan masalah matematis siswa sebesar 14,1\% dan 85,9\% lainnya dipengaruhi oleh factor lain. Meskipun kepercayaan siswa pada matematika pengaruhnya kecil, namun tetap dikatakan mampu mempengaruhi kemampuan pemecahan masalah matematis siswa. seangkan persamaan atau model regresi dari hasil penelitian ini dapat diketahui melalui tabel 5 berikut.

Tabel 5. Coefficients ${ }^{\mathrm{a}}$

\begin{tabular}{|c|c|c|c|c|c|c|}
\hline \multirow{2}{*}{\multicolumn{2}{|c|}{ Model }} & \multicolumn{2}{|c|}{ Unstandardized Coefficients } & \multirow{2}{*}{$\begin{array}{c}\begin{array}{c}\text { Standardized } \\
\text { Coefficients }\end{array} \\
\text { Beta }\end{array}$} & \multirow[b]{2}{*}{$\mathrm{t}$} & \multirow[b]{2}{*}{ Sig. } \\
\hline & & B & Std. Error & & & \\
\hline \multirow[t]{2}{*}{1} & (Constant) & 7.455 & 27.351 & & .273 & .787 \\
\hline & Kepercayaan & .988 & .453 & .375 & 2.179 & .038 \\
\hline
\end{tabular}

Unstandardized Coefficients B pada tabel tersebut menunjukkan model regresi yang terbentuk, sehingga persamaan regresi yang terbentuk diperoleh:

$$
\widehat{\boldsymbol{Y}}=7,455+0,988 \boldsymbol{X}+\epsilon .
$$

Perhatikan bahwa konstanta regresi pada persamaan di atas menunjukkan nilai 7,455. Sedangkan koefisien $X$ menunjukkan pengaruh nilai $X$ terhadap $Y$ prediksi. Artinya jika nilai kepercayaan siswa pada matematika sebesar 1 satuan, maka nilai variabel prediksi akan bertambah sebesar 0,988. Hal ini berarti 
kepercayaan siswa pada matematika memiliki pengaruh yang positif terhadap kemampuan pemecahan masalah matematis siswa. sehingga dengan kata lain dapat dikatakan, semakin tinggi kepercayaan siswa pada matematika, maka kemampuan pemecahan masalah matematis siswa juga akan semakin meningkat.Hasil penelitian ini sejalan dengan pendapat Malmivuori (1994) yang menyatakan bahwa tidak hanya guru yang berpengaruh pada hasil pembelajaran, tetapi juga sistem kepercayaan siswa yang didalamnya terdapat kepercayaan terhadapmatematika.Hal ini didukung oleh Gómez-Chacón dkk (2011) yang mengungkapkan bahwa nilai dari tes kognitif, kepercayaan pada matematika, dan kepercayaan pada kompetensi sendiri dapat menjadi prediksi dari kinerja matematika

Hasil penelitian ini juga sesuai hasil penelitian Pimta, Tayruakham, dan Nuangchalerm (2009) yang menyatakan bahwafaktor yang mempengaruhi kemampuan pemecahan masalah ada 2, yaitu langsung dan tidak langsung. Faktor langsung adalah sikap pada matematika, selfesteem,dan perilaku mengajar guru. Faktor yang tidak langsung adalah motivasi dan efikasi diri. Sejalan juga dengan hasil penelitian Adnan, Zakaria, dan Maat (2012) mengemukakan bahwa ada hubungan yang signifikan antara kepercayaan pada matematika, pemahaman konsep danpengalaman matematis.

\section{SIMPULAN DAN SARAN}

\section{Simpulan}

Kepercayaan siswa pada matematika yang diukur menggunakan angket diperoleh rata-rata dari 31 siswa sebesar 60,23 dengan standar deviasi sebesar 3,66. Sedangkan kemampuan pemecahan masalah matematis siswa diperoleh rata-rata siswa sebesar 66,94 dengan standar deviasi sebesar 9,63. Kepercayaan siswa pada matematika dan kemampuan pemecahan masalah matematis siswa tergolong cukup.Ada pengaruh kepercayaan siswa pada matematika terhadap kemampuan pemecahan masalah matematis siswa ditunjukkan dengan $\mathrm{F}$ hitung $(4,746) \geq \mathrm{F}$ tabel $(4,18)$ atau angka signifikansi pada ANOVA0,038 $\leq 0.05$. Besarnya pengaruh kepercayaan siswa pada matematika terhadap kemampuan pemecahan masalah matematis siswa sebesar $14,1 \%$. Persamaan regresi yang diperoleh $\widehat{\boldsymbol{Y}}=7,455+0,988 \boldsymbol{X}+\epsilon$. Artinya jika nilai kepercayaan siswa pada matematika sebesar 1 satuan, maka nilai variabel prediksi akan bertambah sebesar 0,988. Semakin tinggi kepercayaan siswa pada matematika, maka kemampuan pemecahan masalah matematis siswa juga akan semakin meningkat.

\section{Saran-saran}

Berdasarkan hasil penelitian ini, maka saran yang dapat disampaikan sebagai berikut:

1. Guru atau yang terlibat dalam proses belajar mengajar matematikadiharapkan mampu menanamkan keprcayaan matematika kepada siswa.

2. Kemampuan pemecahan masalah matematis siswa dapat ditingkatkan melalui peningkatan kepercayaan siswa terhadap matematika.

\section{DAFTAR PUSTAKA}

Adams, Dennis \& Hamm, Mary. (2010). Demystify math, science, and technology: creativity, innovation, and problem solving. United Kingdom: Rowman \& Littlefield Education.

Adnan, M., Zakaria, E., \&Maat, S. M. (2012). Relationship between mathematics beliefs, conceptual knowledge and mathematical experience among preservice teachers. Procedia - Social and Behavioral Sciences, 46, $1714-1719$.

Brookhart, S.M. (2010). How to Assess Higher-Order Thingking Skills In Your Classroom. United States of Amerika: ASCD Member Book.

Bruning, R.H., Schraw, G. J., \& Norby, M. M. (2011). Cognitive psychology and instruction (5th Ed). Boston, USA: Pearson Education, Inc.

Goldin, G., Rösken, B., \& Törner, G. (2009). Beliefs - no longer a hidden variable in mathematical teaching and learning processes. Dalam Jürgen Maßß \& Wolfgang Schlöglmann (Eds), Beliefs and Attitudes in Mathematics Education (pp.1-18). Rotterdam, The Netherlands: Sense Publishers.

Gómez-Chacón, I. M., García-Madruga, J. A., Rodríguez, R., Vila, J. Ó., \& Elosúa, M. R. (2011). Mathematical beliefs and cognitive reflection: Do they predict academic chievement?. Proceedings of the MAVI-17 Conference, Ruhr-Universität Bochum, Germany, 64-73. 
Hudoyo, H. (1979). Pengembangan kurikulum matematika \& pelaksanaanya di depan kelas. Surabaya : Usaha Nasional.

Kloosterman, Peter. (2002). Beliefs about mathematics and mathematics learning in the secondary school: Measurement and implications for motivation. Dalam Leder, G.C., Pehkonen, W., \& Torner, G. (Eds.), Beliefs; A Hidden Variable in Mathematics Education? (pp.247-269). London: Kluwer Academics Publisher.

Malmivuori, Marja-Liisa. (1994). Study on affective factors in mathematics learning. Proceedings of the Nordic Conference on Mathematics Teaching (NORMA-94), Lahti, 127-131.

Mutodi, Paul \& Ngirande, Hlanganipai. (2014). The influence of students perceptions on mathematics performance: A case of a selected high school in South Africa. Mediterranean Journal of Social Sciences, 5(3), 431-445.

Nitko, A. J. \& Brookhart, S. M. (2011). Educational assesment of students $6^{\text {th }}$ edition. USA: Pearson Education, Inc.

Op't Eynde, P., De Corte, E., \& Verschaffel, L. (2002).Framing student'smathematics-related beliefs: a quest for conceptual clarity and acomprehensive categorization.Dalam Leder, G.C., Pehkonen, W.,\&Torner, G. (Eds.), Beliefs; A Hidden Variable in MathematicsEducation?(pp.13-37). London: Kluwer Academics Publisher.

Pehkonen, E., \& Pietilä, A. (2003).On relationships between beliefs andknowledge in mathematics education. Makalah disajikan pada CERME 3:Third conference of the European society forresearch in mathematicseducation, Bellaria, Italy.

Pehkonen, Erkki. (2001). A hidden regulating factor in mathematics classrooms:Mathematics-related beliefs. Dalam Ahtee, M., Bjorkqvist, O., Pehkonen,E., \& Vatanen, V. (Eds.), Research on Mathematics and ScienceEducation (pp.11-35). Finland: University of Jyvaskyla, Institute forEducational Research.

Pimta, S., Tayruakham, S., \& Nuangchalerm, P. (2009). Factors influencing mathematic problem-solving ability of sixth grade students. Journal of Social Sciences, 5(4), 381-385. 